\title{
Pengaruh Latihan Fisik Terhadap Peningkatan Kadar PGC 1 Alpha Pada Otak Mencit Jantan
}

\author{
Renni Hidayati Zein, SST.FT., M.Bmd \\ Program Studi D-III Fisioterapi Fakultas Farmasi dan Ilmu Kesehatan Universitas Abdurrab \\ Jl. Riau Ujung no. 73 Pekanbaru \\ Email : renni.hidayati.z@univrab.ac.id
}

\begin{abstract}
Bacground: The brain is an organ that is susceptible to degenerative processes. When the brain begins to age, there will be a decrease in brain function which is at risk of decreased cognitive function. Aerobic physical exercise can cause oxidative stress by increasing the formation of ROS from aerobic metabolism of muscle cells during physical exercise and cellular stress caused by ROS can trigger cell repair reactions. ROS is a very reactive oxygen-derived free radical, an important generator in the production of ROS is

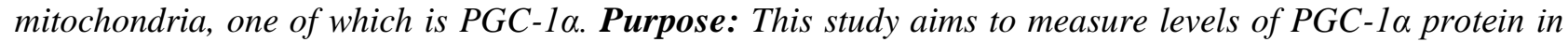
male mice given exercise. Research Method male mice were divided into 2 groups consisting of 6 mice in the control group, 6 mice in the Exercise group with a total of 12 male mice, each 6 weeks old. This research was conducted for 8 weeks using ELISA laboratory techniques to analyze the PGC-1 $\alpha$ protein. Result: : This study showed that there was an increase in the levels of PGC-1 $\alpha$ in the brains of male mice after laboratory examination and then continued with statistical tests, the highest value of PGC-1 $\alpha$ levels in the brains of male mice in the aerobic exercise group was obtained. Conclusion: The administration of aerobic exercise to male mice for 8 weeks had an effect on PGC-1 1 levels in the brains of male mice.
\end{abstract}

Keywords: PGC-1 $\alpha$, Exercise, Brain.

\begin{abstract}
ABSTRAK
Latar belakang: Otak merupakan organ tubuh yang rentan terhadap proses degeneratif. Saat otak mulai menua akan terjadi penurunan fungsi otak yang berisiko terjadi penurunan fungsi kognitif. Latihan fisik aerobik dapat menyebabkan timbulnya stress oksidatif melalui peningkatan pembentukan ROS yang berasal dari metabolisme aerobik sel-sel otot selama latihan fisik tersebut dan stress seluler yang diakibatkan karena ROS dapat memunculkan reaksi perbaikan sel. ROS merupakan radikal bebas turunan oksigen yang sangat reaktif, generator penting dalam produksi ROS adalah mitokondria yang salah satu proteinnya

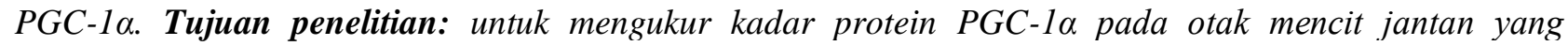
diberikan exercise. Metode penelitian: mencit jantan dibagi menjadi 2 kelompok yang terdiri dari 6 ekor mencit kelompok kontrol,6 ekor mencit kelompok Exercise dengan total jumlah 12 ekor mencit jantan masing-masing berusia 6 minggu. Penelitian ini dilakukan selama 8 minggu menggunakan teknik laboratorium ELISA untuk menganalisa protein PGC-1 $\alpha$ dilakukan. Hasil: Penelitian ini menunjukkan bahwa terjadi peningkatan kadar PGC-1 $\alpha$ pada otak mencit jantan setelah dilakukan pemeriksaan laboratorium dan kemudian dilanjutkan uji statistik diperoleh nilai tertinggi kadar PGC-1 $\alpha$ pada otak mencit jantan pada kelompok perlakuan aerobic exercise. Kesimpulan: Pemberian aerobic exercise pada mencit jantan selama 8 minggu berpengaruh terhadap kadar PGC-1 $\alpha$ pada otak mencit jantan.
\end{abstract}

Kata kunci: PGC-1 $\alpha$, Exercise, Brain. 


\section{PENDAHULUAN}

Otak merupakan organ tubuh yang rentan terhadap proses degeneratif. Saat otak mulai menua akan terjadi penurunan fungsi otak yang berisiko terjadi penurunan fungsi kognitif. Kognitif merupakan kemampuan pengenalan dan penafsiran seseorang terhadap lingkungannya berupa kemampuan atensi, bahasa, memori, visuospasial dan fungsi eksekutif. Gangguan kognitif terjadi ketika salah satu atau lebih dari fungsi kognitif mengalami gangguan ${ }^{(1)}$.

Penurunan fungsi kognitif dapat berupa penurunan fungsi memori jangka pendek, gangguan atensi, gangguan judgemen, gangguan orientasi, penurunan keterampilan visual-spatial dan penurunan keterampilan menyelesaikan masalah (problem-solving skills). Hal ini terjadi karena adanya proses degenerasi kognitif (2). Beberapa contoh penyakit neurodegenerasi seperti Alzheimer,demensiadan penyakit Parkinson desease. Degeneratif kognitif ini dapat berlangsung secara progresif ${ }^{(3)}$.

Latihan fisik merupakan salah satu tekanan ekstrim yang diterima oleh tubuh, namun dalam penelitian Peake et al (2007) mengungkapkan bahwa latihan fisik aerobik dapat menyebabkan timbulnya stress oksidatif melalui peningkatan pembentukan ROS yang berasal dari metabolisme aerobik sel-sel otot selama latihan fisik tersebut dan stress seluler yang diakibatkan karena ROS dapat memunculkan reaksi perbaikan sel. Generator penting dalam produksi ROS adalah mitokondria ${ }^{(4)}$

ROS merupakan radikal bebas turunan oksigen yang sangat reaktif ${ }^{(5)}$. Selama ini penelitian menunjukkan bahwa ROS merupakan senyawa yang dapat menghancurkan sel dalam mekanisme stress oksidatif. Namun dalam penelitian yang dilakukan oleh Poljsak dan Malisav (2012) mengungkapkan bahwa stress seluler yang diakibatkan karena ROS dapat memunculkan reaksi perbaikan sel. Mekanisme tersebut terjadi karena hasil adaptasi metabolik yang disebut dengan survival mechanisme

Survival mechanisme dipengaruhi oleh pembaharuan sel dan organel dalam mekanisme Preconditioning hypoxia menghasilkan protein P38. Protein ini berfungsi memberikan signal untuk terjadinya regenerasi sel otot. Mekanisme ini terjadi karena sel otot jantung membutuhkan energi yang diperoleh dari organel sel mitokondria. Protein ini, juga ikut serta dalam peningkatan fungsi mitokondria yang merupakan organel penting dalam metabolisme tersebut ${ }^{(6)}$. Pada saat kekurangan oksigen dalam latihan fisik, tubuh akan mengaktifkan adenosin monophosphat kinase (AMPK), protein TNF alpha dan MEF2 yang mengaktifkan FOXO1 meningkat. FOXO1 atau forkhead box protein merupakan protein yang akan merespon munculnya protein lain dalam biogenesis mitokondria dan perlindungan sel neuron di otak ${ }^{(7)}$.

Penelitian oleh Bostrom et al (2012) menyebutkan tentang peranan latihan fisik terhadap peningkatan produksi protein FNDC5, yang mana protein FNDC5 ini ekspresi gennya diatur oleh protein PGC-1 $\alpha$, dimana kinerja kedua protein ini yaitu protein PGC- $1 \alpha$ dan protein FNDC5 saling berkorelasi dengan baik dan memiliki peranan yang penting dalam perkembangan neuron. Peningkatan yang terjadi pada PGC-1 $\alpha$ ini juga akan meningkatkan kadar FNDC5 di otak, sehingga bila terjadi peningkatan protein PGC- $1 \alpha$ dan FNDC5 di otak terutama di korteks saraf primer akan dapat meningkatkan ekspresi BDNF dan gen saraf di otak melalui aktifasi dari irisin karena PGC- $1 \alpha$ dan FNDC5 yang mengatur ekspresi BDNF di dalam otak terutama bagian hipokampus ${ }^{(8)}$.

\section{TinjauanPustaka}

\subsection{Definisi Otak}

Otak adalah organ vital yang terdiri dari 100200 milyar sel aktif yang saling berhubungan dan bertanggung jawab atas fungsi mental dan intelektual kita. Otak terdiri dari sel-sel otak yang disebut neuron. Neuron adalah sel khusus, ditemukan di otak, ganglia (kelompok neuron berada Di luar sistem saraf pusat), dan beberapa organ sensorik $^{(9)}$.

Neurodegeneratif merupakan suatu kondisi patologis pada sel saraf dimana sel saraf tersebut mengalami kehilangan struktur atau fungsi sebenarnya secara progresif ${ }^{(10)}$. Beberapa penyakit yang terkait dengan kondisi neurodegeneratif adalah penyakit Alzheimer, autis, dan Down syndrome. Pada penderita penyakit Alzheimer terdapat beta amyloid yang berlebih pada otaknya sehingga protein foldingnya menjadi terganggu dan membentuk plak ${ }^{(11)}$. 


\section{Jurnal Ilmiah Fisioterapi (JIF) Volume 4 Nomor 01 Februari 2021}

Penyakit neurodegeneratif seringkali dikarakterisasi dengan penumpukan beta amyloid yang berlebih. Adapun upaya untuk menyingkirkan plak beta amyloid ini juga dapat diketahui meningkatkan kognitif pada pasien penderita neurodegeneratif. Beta amyloid juga dapat meningkatkan kematian sel-sel saraf yang dikarakterisasi oleh sel-sel saraf yang degeneratif.

\subsubsection{Peranan PGC-1a di Mitokondria Jaringan Otak}

Pembentukan, pemeliharaan, dan reorganisasi sinapsis sangat penting untuk perkembangan otak dan tanggapan dari sirkuit saraf untuk tantangan lingkungan. Di sini kita menggambarkan peran baru untuk Peroksisom proliferator-activated receptor gamma co-aktivator (PGC-1 $\alpha$ ), pengatur master biogenesis mitokondria, dalam pembentukan dan pemeliharaan cabang-cabang dendritik dalam otak (Cheng et al., 2012). Peroxisome ProliferatorActivated Receptor $\gamma$ Coactivator-1 $\alpha$ (PPARGCA-1 $\alpha$, PGC-1 $\alpha$ ) adalah transkripsi pengatur gen yang terlibat dalam metabolism energi. PGC-1 $\alpha$ merupakan regulator utama dari biogenesis mitokondria ${ }^{(12)}$.

\subsection{Metode dan teknik intervensi}

\subsubsection{Ethics statement}

Semua protokol telah disetujui oleh Komite Etik Riset Universitas Sriwijaya. Semua upaya dilakukan untuk meminimalkan penderitaan hewan.

\subsubsection{Latihan Fisik}

Latihan fisik adalah setiap gerakan tubuh yang dihasilkan oleh otot yang memerlukan energi dalam aktivitasnya ${ }^{(13)}$. Dari pengertian tersebut, dapat dijelaskan bahwa latihan fisik merupakan proses pelatihan yang memerlukan energi, dilaksanakan secara teratur, terencana, menggunakan pola dan sistem tertentu, metodis, berkesinambungan dari yang sederhana ke yang kompleks, dari yang mudah ke yang sulit dan latihan dilakukan beberapa kali dalam satu minggu. Secara umum latihan yang terdapat dalam kegiatan olah raga terdiri dari 2 jenis latihan yaitu latihan yang bersifat aerobik dan latihan yang bersifat anaerobik. Jenis olahraga yang bersifat aerobik seperti joging, marathon, dan juga bersepeda sedangkan jenis olahraga yang bersifat anaerobik yang membutuhkan tenaga besar dalam waktu singkat seperti push-up, sprint dan angkat berat $^{(14)}$.

Latihan aerobik adalah suatu bentuk latihan atau olahraga yang dalam penggunaan energinya menggunakan proses oksidatif dalam menghasilkan ATP sebagai energi dasar untuk semua sel. Latihan aerobik mempunyai pengaruh pada daya tahan jantung paru. Latihan aerobik sebaiknya dilakukan dengan frekuensi 3-5 kali perminggu dengan durasi latihan 20-30 menit setiap kali latihan. Latihan ini merupakan latihan olahraga yang terdiri dari intensitas ringan hingga sedang yang dapat dilakukan secara kontinu dalam waktu yang cukup relatif lama ${ }^{(15)}$.

\subsection{Pengukuran}

Pengukuran Kadar PGC-1 a dengan cara Isolasi jaringan otak dilakukan segera setelah dibunuh dengan cara dibius dengan menggunakan choloroform. Setelah tikus mati dilakukan autopsy dengan membuka dinding kepala tikus. Lalu ambil otak dan timbang berat dari organ tersebut. Kemudian jaringan sampel dicuci dengan PBS $1 \%$ hingga cairan hasil pencucian jernih. PBS 1\% bersama jaringan sampel di sentrifuge 3000rpm, selama 20menit didapatlah pellet dan supernatant. Supernatant diambil untuk pemeriksaan PGC-1 $\alpha$. Konsentrasi kadar PGC-1 $\alpha$ diukur dengan menggunakan Mouse PGC 1 $\alpha$ ELISA Kit Sunlong Biotech Co., Ltd.

Data dari hasil pemeriksaan kadar PGC 1 alpha menggunakan metode ELISA dan akan diuji dengan mengunakan uji Shapiro-Wilk untuk mengetahui normalitas distribusi data. Berdasarkan uji tersebut dapat diketahui apakah data penelitian akan diuji dengan menggunakan uji statistik parametrik atau nonparametrik. Jika didapatkan distribusi data normal, maka dilakukan uji perbedaan kadar PGC 1 alpha pada setiap kelompok dengan menggunakan uji statistik dengan analysis of variance (ANOVA) dengan ketentuan, sebagai berikut: 1) jika $\mathrm{p}<0,05$, maka ada perbedaan yang bermakna; 2) jika $\mathrm{p}>$ 0,05 , maka tidak ada perbedaan yang bermakna.

\section{Metode Penelitian}

\subsection{Rancangan Penelitian}

Jenis penelitian ini adalah eksperimental quasi dengan menggunakan rancangan posttest only control group design dalam bentuk in vivo. Sampel dibagi menjadi 2 kelompok yaitu kelompok 1 tidak mendapatkan perlakuan dan kelompok 2 mendapatkan perlakuan latihan fisik. 
Jurnal Ilmiah Fisioterapi (JIF) Volume 4 Nomor 01 Februari 2021

\subsection{Tempat dan waktu penelitian}

Penelitian ini dilaksanakan di 2 tempat. Eksperimen hewan coba dilakukan di Animal House Fakultas Kedokteran Universitas Sriwijaya dan pemeriksaan kadar PGC-1 alpha jaringan otak mencit dilakukan di Laboratorium Biomedik Fakultas Kedokteran Universitas Sriwijaya. Waktu penelitian dilaksanakan selama 2 bulan dimulai pada 18 September - 25 November 2017.

\subsection{Subjek Penelitian}

Subyek penelitian ini menggunakan mencit putih jantan yang diperoleh dari Unit Pengelolaan Hewan Laboratorium Institus Pertanian Bogor yang kemudian dipelihara di Animal House Fakultas Kedokteran Universitas Sriwijaya.

Sampel adalah mencit jantan (Mus musculus) jantan galur Swiss Webster dengan umur 6-8 minggu, berat badan 20-30 gram yang memenuhi kriteria. Subjek penelitian dibagi menjadi 4 kelompok secara random, yaitu kelompok tanpa perlakuan (KP1), Kelompok dengan Latihan fisik (KP2).

\subsection{Prosedur Intervensi}

\subsubsection{Pemberian Latihan Menggunakan running wheel.}

Untuk kelompok perlakuan dengan latihan fisik, mencit diperkenalkan dengan alat Running wheel dengan cara melatih mencit berlari diatas alat tersebut setiap hari dengan kecepatan dan waktu yang sudah ditetapkan. Hal ini bertujuan agar pada saat penelitian dilakukan, mencit sudah familiar dengan alat running wheel yang dipakai.

Pengenalan alat dilakukan dengan kecepatan 5 meter/menit dengan durasi 5 menit dan ditingkatkan menjadi 7 meter/menit hingga 10 menit berikutnya. Pengenalan ini dilakukan setiap hari selama seminggu sebelum diberikan latihan fisik yang sesungguhnya ${ }^{(16)}$.

Perlakuan pada tikus aerobik diberikan selama 30 menit dengan kecepatan konstandengan kecepatan 10-12 $\mathrm{m} / \mathrm{menit}$. Latihan didahului dengan pemanasan dan diakhiri dengan pendinginan selama 5 menit dengan kecepatan 6 $\mathrm{m} / \mathrm{menit}$, sehingga total waktu latihan adalah 40 menit per sesi. Perlakuan dilakukan 5 sesi per minggu selama 4 minggu ${ }^{(17)}$.

\subsubsection{Uji Morris Water Maze (MWM)}

Uji MWM dilakukan pada hari ke- 56 untuk menilai fungsi memori spasial dan kognisi pada mencit. Mencit akan ditempatkan pada bejana plastik berdiameter $1.5 \mathrm{~m}$ dengan kedalaman $20 \mathrm{~cm}$ yang akan diisi bersih dengan volume $18 \mathrm{~L}$. Prosedur test MWM akan dibagi menjadi 2 tahapan yaitu pre-training dan uji coba yang dilakukan selama 3 hari dengan tahapan sebagai berikut ${ }^{(18)}$.

\section{Hasil dan Pembahasan \\ 4.1 Hasil Penelitian}

Karakteristik berdasarkan Pemberian Pakan yaitu terdiri dari kelompok kontrol dimana kelompok kontrol tidak diberikan perlakuan apapun, kelompok dengan perlakuan latihan fisik. kelompok dengan perlakuan latihan fisik masing - masing sebanyak 7 ekor mencit. Pada hari ke-34 masing masing mencit mati dari setiap kelompok menjadi 6 ekor setiap kelompoknya dan total 12 sampel.

Setelah diadaptasi selama 7 hari mencit putih (Mus Musculus) galus swiss webster ditimbang dengan menggunakan timbangan digital. Hasil pengukuran berat badan rata-rata mencit keempat kelompok dilihat pada Tabel berikut ini :

\begin{tabular}{lllll}
\hline Kelompok & $\mathbf{N}$ & $\begin{array}{l}\text { BB } \\
\text { Sebelum } \\
\text { (gram) }\end{array}$ & $\begin{array}{l}\text { BB } \\
\text { sesudah } \\
\text { (gram) }\end{array}$ & $\Delta \mathbf{B B}$ \\
\hline Kontrol & 6 & $28,00 \pm 1,67$ & $35,80 \pm 3,54$ & 7,80 \\
Latihan & 6 & $28,00 \pm 1,67$ & $32,17 \pm 2,63$ & 4,17 \\
Fisik & & & & \\
\hline Jumlah & 12 & & & \\
\hline
\end{tabular}

Tabel diatas menunjukkan bahwa terjadi peningkatan berat badan paling tinggi pada hewan coba kelompok kontrol. Sedangkan pada kelompok perlakuan latihan fisik hanya terjadi sedikit peningkatan.

\subsubsection{Pengaruh Latihan Fisik Terhadap kadar PGC-1 $\alpha$}

Untuk melihat perbandingan apakah terdapat perbedaan yang bermakna rerata kadar PGC-1 $\alpha$ pada jaringan otak antar kelompok kontrol dan kelompok perlakuan kita menggunakan uji Oneway ANOVA. Hasil uji Oneway ANOVA dijelaskan pada Tabel berikut:

\begin{tabular}{llrl}
\hline Kelompok & $\begin{array}{c}\text { Kadar PGC-1 } \\
\text { Mean } \pm \\
(\mathrm{pg} / \mathrm{ml})\end{array}$ & $\begin{array}{c}\alpha * * \\
\text { SD }\end{array}$ & \\
\hline Kontrol & $77,57 \pm 4,91$ & & \\
Latihan Fisik & $109,70 \pm 4,45$ & & $<0,001$ \\
\hline
\end{tabular}


Berdasarkan Tabel hasil uji Oneway ANOVA didapatkan bahwa terjadi peningkatan kadar PGC-1 $\alpha$ jaringan otak mencit jantan disetiap kelompok. Terdapat perbedaan yang bermakna $(\mathrm{p}<0,05)$ kadar PGC-1 $\alpha$ otak pada kedua kelompok yaitu kelompok kontrol, kelompok latihan fisik.

Setelah didapatkan hasil dari uji ANOVA, untuk mengetahui apakah terdapat perbedaan yang bermakna rerata kadar PGC-1 $\alpha$ otak pada masing masing kelompok dengan melakukan uji post hoc. Hasil uji ini merupakan hasil uji untuk mengetahui terdapatnya perbedaan nilai rerata antar kelompok guna untuk mengetahui kelompok mana saja yang saling bermakna. Perbedaan Nilai Rerata Kadar PGC-1 $\alpha$ di Masing-masing Kelompok,

Hasil Uji Post Hoc

\begin{tabular}{lll}
\hline & Kontrol & Lat. Fisik \\
\hline Kontrol & & 0,000 \\
Latihan Fisik & 0,000 & \\
\hline
\end{tabular}

Tabel menunjukkan hasil bahwa hampir semua kelompok menunjukkan adanya perbedaan yang bermakna $(p<0,05)$ terhadap nilai kadar PGC-1 $\alpha$ pada jaringan otak mencit jantan antara tiap-tiap kelompok.

\subsubsection{Uji Kognitif MWM}

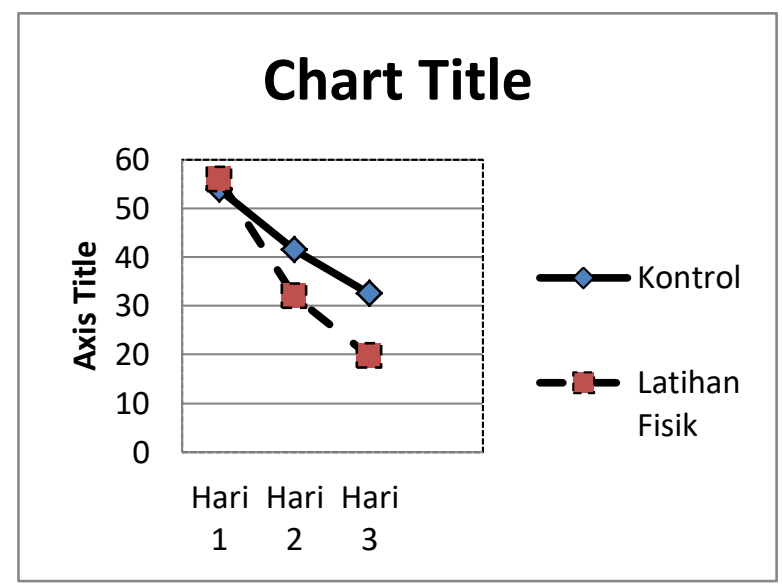

Gambar diatas menunjukkan bahwa pada hari pertama tidak ada perbedaan rata-rata waktu laten untuk menemukan flat pijakan $(\mathrm{p}=0,731)$. Setelah beberapa uji coba, waktu laten untuk menemukan flat pijakan semakin cepat. Pada hari ketiga, terlihat ada perbedaan rata-rata waktu laten untuk menemukan flat pijakan $(\mathrm{p}=0,000)$ dimana waktu laten terlama adalah pada kelompok kontrol dan yang tercepat pada kelompok latihan fisik.

\subsection{Pembahasan}

\subsubsection{Karakter Hewan Coba}

Penelitian ini dilakukan pada mencit putih (mus musculus) galur swiss webster jantan dengan usia yang rata-rata hampir sama yaitu 6 minggu saat penelitian ini akan dimulai. Mencit dipelihara ditempat yang sama, mencit juga berasal dari 1 jenis galur yang sama dan mendapatkan minum dan makan dengan jenis makanan yang sama pula. Oleh karena itu, pada penelitian ini diharapkan keempat kelompok mencit memiliki karakteristik yang homogen.

Berdasarkan hasil penelitian ini didapatkan bahwa, terjadi peningkatan berat badan (BB) selama proses penelitian terutama pada kelompok kontrol (KONTROL) yaitu sebesar (7,8/gram) dari hasil pengukuran selisih berat badan sebelum dan sesudah penelitian. Hal ini juga berlaku pada kelompok perlakuan dengan pemberian latihan fisik selama kurang lebih 8 minggu dengan intensitas latihan 5 kali dalam seminggu.. Semua kelompok perlakuan setelah dilakukan eksperimen menunjukkan peningkatan berat badan, namun selisih berat badan pada kelompok yang diberikan perlakuan tidak sebesar dengan nilai kelompok control ${ }^{(19)}$.

Pada penelitian ini terlihat adanya pengaruh dari perbedaan intervensi latihan fisik terhadap berat badan (BB) mencit jantan. Hal ini dapat terjadi karena pada kelompok kontrol BB meningkat dikarenakan kelompok kontrol tidak diberikan perlakuan apapun sehingga jumlah kalori menumpuk didalam tubuh akibat tidak adanya proses pembakaran kalori yang merupakan efek dari latihan fisik ditambah lagi pada kelompok kontrol tidak adanya pengaturan pola makan. Sedangkan pada kelompok latihan fisik terjadi peningkatan BB dikarenakan adanya penambahan masa otot disebabkan oleh latihan fisik. Perubahan tersebut banyak dipengaruhi oleh jenis dan lamanya latihan. Penambahan masa otot pada latihan fisik terjadi karena bertambahnya volume serabut otot (myofibril) yang bertambah banyak sehingga sel otot membesar yang disebut hypertropi ${ }^{(20)}$.

\subsubsection{Kadar PGC-1 $\alpha$ pada Otak Mencit Jantan Setelah Pemberian Latihan Fisik.}

Penelitian ini mengukur kadar PGC $1 \alpha$ pada otak mencit untuk menilai keberhasilan latihan fisik yang dilakukan, dimana PGC $1 \quad \alpha$ tersebut merupakan regulator utama dari biogenesis 


\section{Jurnal Ilmiah Fisioterapi (JIF) Volume 4 Nomor 01 Februari 2021}

mitokondria yang berperan dalam pembentukan dan pemeliharaan duri dendritik dalam otak/neuron. Banyak penelitian yang membuktikan bahwa latihan fisik dapat meningkatkan kadar PGC 1 a pada mencit, yang diyakini berperan pada keseimbangan oksidatif di otak/neuron ${ }^{(21)}$.

Hasil pengukuran kadar PGC 1 a pada jaringan otak mencit jantan setiap kelompok dilihat dari hasil rerata kadar PGC $1 \quad \alpha$ setelah dilakukan eksperimen selama 8 minggu terlihat adanya perbedaan hasil yang signifikan. Pada hasil penelitian terlihat nilai rerata kelompok perlakuan latihan fisik terbukti lebih tinggi dibandingkan kelompok kontrol yang tanpa diberikan perlakuan apapun yaitu pada kelompok latihan fisik nilai rerata diperoleh sebesar 109,70 (pg/ml) sedangkan pada kelompok kontrol sebesar 77,57 (pg/ml). Hal ini membuktikan bahwa latihan fisik terbukti dapat meningkatkan kadar PGC $1 \alpha$ pada jaringan otak yang mana protein PGC- $1 \alpha$ ini terlibat dalam pembentukan dan pemeliharaan duri dendrit di otak sehingga terbukti meningkatkan kemampuan otak/neuron untuk melakukan neuroplastisitas ${ }^{(22)}$.

Penelitian yang dilakukan oleh mattson (2012) membuktikan efek latihan terhadap otak/neuron yang paling jelas terlihat dalam hippocampus dan dentate gyrus, sebuah bagian dari otak yang berfungsi untuk fungsi kognitif. Efek latihan fisik di otak akan menyebabkan peningkatan aliran darah ke otak sehingga terjadilah perubahan morfologi di dendrit dan duri dendritik yang akan berakibat baik dalam peningkatan plastisitas sinaps dan neurogenesis di dentate gyrus.

Penelitian lainnya yang juga mendukung penelitian ini, menyebutkan tentang peranan latihan fisik terhadap peningkatan produksi protein FNDC5, yang mana protein FNDC5 ini ekspresi gennya diatur oleh protein PGC- $1 \alpha$, dimana kinerja kedua protein ini yaitu protein PGC-1 $\alpha$ dan protein FNDC5 saling berkorelasi dengan baik dan memiliki peranan yang penting dalam perkembangan neuron. Peningkatan yang terjadi pada PGC-1 $\alpha$ ini juga akan meningkatkan kadar FNDC5 di otak, sehingga bila terjadi peningkatan protein PGC- $1 \alpha$ dan FNDC5 di otak terutama di korteks saraf primer akan dapat meningkatkan ekspresi BDNF dan gen saraf di otak melalui aktifasi dari irisin karena PGC- $1 \alpha$ dan FNDC5 yang mengatur ekspresi BDNF di dalam otak terutama bagian hipokampus ${ }^{(23)}$.
BDNF (brain derived neurorophic factor) merupakan neutropin utama yang memperantarai proses plastisitas sinap, pada latihan fisik mampu memicu pelepasan BDNF, yaitu suatu faktor yang memungkinkan satu sel saraf berkomunikasi dengan sel saraf yang lain (Vaynman et al., 2004). BDNF berfungsi untuk mendorong pertumbuhan dan diferensiasi neuron baru (neurogenesis) serta mendukung kemampuan neuron untuk bertahan hidup. Hal ini di sebabkan peranan dari PGC- $1 \alpha$ yang menjadi regulator utama dalam peningkatan ekspresi gen. Oleh karena itu PGC-1 $\alpha$ dan biogenesis mitokondria memainkan peran penting dalam pembentukan dan pemeliharaan duri dendritik hipokampus dan sinapsis sebagai bentuk pencegahan penyakit neurodegeneratif ${ }^{(24)}$.

Hasil analisis statistik pada penelitian ini yang mendapatkan hasil paling tinggi terdapat pada kelompok perlakuan dengan kombinasi latihan fisik dan caloric restriction yaitu sebesar 119,17 (pg/ml) sedangkan nilai rerata paling kecil untuk kadar PGC $1 \alpha$ terdapat pada kelompok kontrol yaitu sebesar $77,57(\mathrm{pg} / \mathrm{ml})$ dimana pada kelompok tersebut tidak dilakukan perlakuan apapun baik itu latihan fisik maupun caloric restriction. Kedua kelompok ini menunjukkan perbedaan hasil yang bermakna $(\mathrm{p}<0,05)$. Hal ini membuktikan bahwa latihan fisik dengan caloric restriction yang dilakukan bersamaan akan menyebabkan terjadinya peningkatan kadar PGC $1 \alpha$ terutama pada jaringan otak mencit jantan sehingga dapat meningkatkan kemampuan neuron/otak untuk melakukan neuroplastisitas.

Latihan fisik dapat mempengaruhi proses neuroplastisitas melalui 3 mekanisme utama. Pertama, latihan fisik dapat meningkatkan proses neurogenesis dan neuroplastisitas melalui peningkatan berbagai neurotransmitter, neurotropin dan berbagai proses intraseluler yang memediasi proses ini. Kedua, latihan fisik akan meningkatkan VEGF (vaskular endhotelia growth hormon) yang memfasilitasi proses angiogenesis dan perbaikan vaskularisasi di otak. Ketiga, latihan fisik meningkatkan daya tahan sel neuron dengan mempengaruhi keseimbangan oksidatif di otak ${ }^{(25)}$.

Secara proses molekuler latihan fisik dapat meningkatkan densitas duri dendritik, jumlah sinap dan ekspresi protein-protein seperti PGC $1 \quad \alpha$ (Cheng et al., 2012). Latihan fisik juga menginduksi proses LTP (long term potentiation) dengan cara menurunkan threshold LTP dan meningkatkan sejumlah kaskade intraselular seperti CREB, MAPK 
Jurnal Ilmiah Fisioterapi (JIF) Volume 4 Nomor 01 Februari 2021

dan CaMKII ${ }^{(26)}$. Sehingga hasil akhir dari LTP ini yaitu pertumbuhan seperti BDNF, dimana BDNF ini berperan penting terhadap fungsi kognitif ${ }^{(27)}$.

Selain itu latihan fisik menyebabkan peningkatan transkripsi PGC-1 $\alpha$ dan ERR $\alpha$. Dimana kemampuan PGC-1 $\alpha$ untuk menginduksi FNDC5 ekspresi gen tergantung dari ketersediaan ERR $\alpha$. FNDC5 merupakan pengatur kadar BDNF. Dengan meningkatkan kadar FNDC5 saat latihan akan menyebabkan terjadinya peningkatan kadar BDNF pada jaringan otak, tidak hanya peran dari FNDC5 protein lain pun seperti CREB dan NF-kB pun ikut berperan dalam menginduksi kadar BDNF saat latihan. Sehingga akan terjadi perningkatan dari Fungsi kognitif. Bila di kombinasikan dengan pengaturan pola makan seperti caloric restriction justru akan meningkatkan fungsi kognitif yang lebih baik.

\section{Kesimpulan}

Latihan fisik terbukti dapat meningkatkan kadar PGC-1 $\alpha$ pada jaringan otak mencit jantan yang bermakna $(p<0,05)$ dibandingkan dengan kelompok kontrol. Hal ini terlihat dari perbedaan hasil rerata kelompok latihan fisik yang lebih tinggi dibanding kelompok kontrol yaitu $(109,70 \pm$ $4,45 \mathrm{pg} / \mathrm{ml}$ dengan $77,57 \pm 4,91 \mathrm{pg} / \mathrm{ml})$.

\section{REFERENSI}

[1] Reeve, A., Simcox, E., \& Turnbull, D. (2014). Ageing and Parkinson's disease: Why is advancing age the biggest risk factor? Ageing Research Reviews, 14(100), 19-30.

[2,3] Rodríguez-Bies, E., Calvo, S.S.C., FontánLozano, A., Amaro, J.P., Berral de la Rosa,F,J., Carrión,A,M., Navas,P., LópezLluch, G. (2010) "Muscle Physiology Changes Induced by Every Other Day Feeding and Endurance Exercise in Mice: Effects on Physical Performance". Plos One. 5(11): 1-12.

[5] Halliwell, B. \& Whiteman, M. (2004) Measuring reactive species and oxidative damage in vivo and in cell culture: how should you do it and what do the results mean? Br J Pharmacol, 142:231-55.

[6]. Correia, S.C., Santos, R.X., Perry, G., Zhu, X., Moreira, P.I. \& Smith, M.A. 2010. "Mitochondria: the missing link between preconditioning and neuroprotection". $J$
Alzheimers Dis. 20(2): 75-85.

[7] Cantó, C., \& Auwerx, J. (2009). PGC-1alpha, SIRT1 and AMPK, an energy sensing network that controls energy expenditure. Current Opinion in Lipidology, 20(2), 98-105.

[8,9,11,21,22] Herrington, T. M., Cheng, J. J., \& Eskandar, E. N. (2016). Mechanisms of deep brain stimulation. Journal of Neurophysiology, 115(1), 19-38.

[12] Valero, T. (2014). "Mitochondrial biogenesis: pharmacological approaches". Curr Pharm Des. 20(35): 5507-5509.

[13] Pekik, D., Irianto. (2002). Dasar Kepelatihan. Yogyakarta : FIK UNY

[15] Irawan M.A. 2007. Metabolisme Energi Tubuh \& Olahraga. Jakarta: Sports Sciene Brief.

[16] Palar, C.M., Wongkar, D. \&Ticoalu, S.H.R. (2015). "Manfaat Latihan Olahraga Aerobik Terhadap Kebugaran Fisik Manusia". Jurnal eBiomedik (eBm). 3(1): 319-321.

[17,18,25] Irfannudin, M. 2014. Disertasi. "Pengaruh Olahraga Aerobik Halang Rintang Terhadap Fungsi Kognitif, Ditinjau dari Homeostasis Oksidatif, Angiogenesis, dan Neuroplastisitas Otak Mencit Dewasa". Jakarta: Universitas Indonesia.

[20] Herman, Subarjah,.2009. Latihan Kondisi Fisik.Bandung.

[23]. Boström, P., Wu, J., Jedrychowski, M. P., Korde, A., Ye, L., Lo, J. C., Spiegelman, B. M. (2012). A PGC1 $\alpha$-dependent myokine that drives browning of white fat and thermogenesis. Nature, 481(7382), 463-468.

[24] Li, A., Hoo, R. L. C., Ching, Y. P., Christie, B. R., Lee, T. M. C., So, K.-F. (2016). Physical exercise-induced hippocampal neurogenesis and antidepressant effects are mediated by the adipocyte hormone adiponectin. Proceedings of the National Academy of Sciences of the United States of America, 111(44), 15810

\section{Nama penulis}

1. Renni Hidayati Zein, memperoleh sarjana terapan fisioterapi pada tahun 2014 di Universitas Muhammadiyah Surakarta. Kemudian tahun 2018 telah menyelasaikan master biomedik di Universitas Sriwijaya. Saat ini sebagai Dosen Tetap prodi DIII fisioterapi Pekanbaru 